\title{
Technology, Organizational Structure and Innovation - in Organizations Operating in Poland
}

\author{
Katarzyna WALECKA-JANKOWSKA, Joanna ZIMMER \\ Wroclaw University of Science and Technology, Wrocław, Poland \\ \{katarzyna.walecka-jankowska, joanna.zimmer\}@pwr.edu.pl
}

\begin{abstract}
The article presents the results of empirical research related to determinants of innovation. Authors concentrate on the most important determinants: organizational structure and technology. Both practitioners and theoreticians deal with the problems of managing innovation, seeking its determinants which can emerge by minimizing barriers to the creation and implementation of innovations. Organizational structures and technology are decisive factors for a company's innovation and performance. The purpose of this article is to indicate what type of technology is conducive to the development of innovation and their effective use in the development of enterprise value. Empirical research was carried out using a questionnaire on a sample of 105 organisations operating in Poland that differed in terms of size, sector and ownership model. In order to examine the relationship between the nonroutine technology variable and the subjective level of innovation, regression and variation analysis was performed. All calculations were performed using SPSS packages for Windows. The research presented in this article shows that there is a statistically significant relationship between nonroutine technology and innovation.
\end{abstract}

Keywords: Innovation, Technology, Organizational Structure, Research.

\section{Introduction}

There is widespread agreement among authors, researchers, consultants and thinkers in the field of management that innovation is the central capability for all organisations interested in maximizing the opportunities for success in the 21st century. However, as J. de Cagna said, while the pursuit of innovation cannot absolutely guarantee meaningful growth, it is the best strategy most enterprises have for achieving it in a way can become sustainable over time [4]. Both practitioners and theoreticians deal with the problems of managing innovation, seeking its determinants which can emerge by minimising barriers to the creation and implementation of innovations. On the other hand, innovation can be practised as well as learned. The goal of researchers is to show how to formulate and implement each determinants of innovation (i.e. organizational structure, technology) to promote the development of innovations and their effective use in the development of the long-term value of an organisation. 
According to both theoreticians and practitioners who deal with innovation management, innovation is the key to the survival and development of modern organisations $[6,7,8,13]$. At the same time, technology is also considered an important component of organisational business models by authors such as Leavitt, Krzyżanowski and McKinsey with his 7S model [14, 15, 18]. The purpose of this article is to indicate what type of technology is conducive to the development of innovation and their effective use in the development of enterprise value.

Modern organisations operate in an increasingly dynamic and complex environment. In order to be successful in such conditions, they cannot build their competitive advantage solely on individual products, technologies, or resources; instead, they need to make an effort to be more innovative than their competitors. Changes that take place in their surroundings create a constant need for innovation, which become the main determining factors for competitiveness of both individual companies and regional and national economies as a whole. Innovation is also one of the priorities of the European Union, as supporting innovation is becoming one of the basic purposes of numerous EU projects. Back in the 90's, P. F. Drucker believed that if a company was unable to innovate, it would die [7]. Therefore, a feature of an innovative entrepreneur is to seek changes, to respond to them, and to treat them as opportunities, as well as to continuously aim to create imbalance. Most often, innovation is equated with the physical characteristics of products manufactured. However, in reality, it is process and service innovation that is important for establishing a competitive position of a business. Creating an innovative product is only one of the aspects of building a competitive advantage; the rest of it involves developing an innovative process, as innovations in both of the abovementioned areas are intertwined. In some cases, product innovations require process innovations needed to bring the product to market [9], as well as organisational or even marketing changes. The level of the management's awareness of any limitations in the innovation process resulting from the company's technological processes seems to be vital for the issue at hand.

\section{The concept of innovation}

There are different approaches to innovation, related to different scientific disciplines in which this term originated (in organisation theory, economics, sociology, technology). Most authors emphasise the aspects of the organisation's search for new solutions in response to changes in the environment (both changes in customer needs and changes in organisational environment elements such as technology). Innovation is commonly interpreted as the introduction of a new product and is associated with the production process, especially technology. More rarely is it related to organisational, administrative and cultural changes [12]. The differences in the definition of this concept are also determined by the understanding of innovation as a process or as a result/outcome of a process. However, most definitions emphasise innovation novelty understood objectively (the macroeconomic view: innovation is something absolutely new, pioneering work) and subjectively (the microeconomic view: it is new to the 
organisation, developed and implemented regardless of whether such a solu-tion exists in other organisations). Another common element is that innovation has to lead to the success of the organisation by improving the use of resources or generat-ing socio-economic benefits, and thereby to improve the competitive position of the organisation $[2,18]$. The word 'introduced' is also key here since an important as-pect is the implementation of innovation, not just theoretical assumptions or a new idea. Undoubtedly, innovative activity in organisations should also be reflected in economic profit, personal development of employees, higher job satisfaction, better communication within the organization, higher group consistency, the increase of knowledge and experience resources, the increase of production and economic indicators.

For the research, it was assumed that innovation is a change in the subjective sense (change is new only for the organisation) leading to an improved product, pro-duction process or organisation itself, which was developed to achieve economic or social benefits. Innovation is also the process, in which the final step is to implement new ideas. Thus, innovation is not only the ability of the organisation to create the idea but it should also lead to economic and/or social benefits. It must be completed by the emergence of innovations on the market. The activities related to innovation include changes in both the incremental and radical transformation of the existing solutions. However, the adoption of the subjective understanding allows achieving a high level of innovation even if the organisation implements the changes that exist in other entities, especially when they contribute to the improvement of the organisation [25].

\section{Technology}

Source literature defines technology as: physical objects, artefacts, including products and tools, equipment used for their production, actions and processes constituting production methods, as well as knowledge required to develop and use equipment and production methods (know-how) [10].

According to the definition proposed by [23], technology is "the entire-ty of transformation processes employed by the enterprise, combining both the basic stream of internal transformation and all purchases needed to power the process, as well as the enterprise's outflow" [23]. It should be considered that literature's sources link technology to the individual features of the organisational structure. One of the first typologies of technology was proposed by J. Woodward [10] (research indicated a correlation between the organisational structure and efficiency, when the types of technology used by the organisation are considered) as cited in [10]. The typology is presented in Fig. 1. 


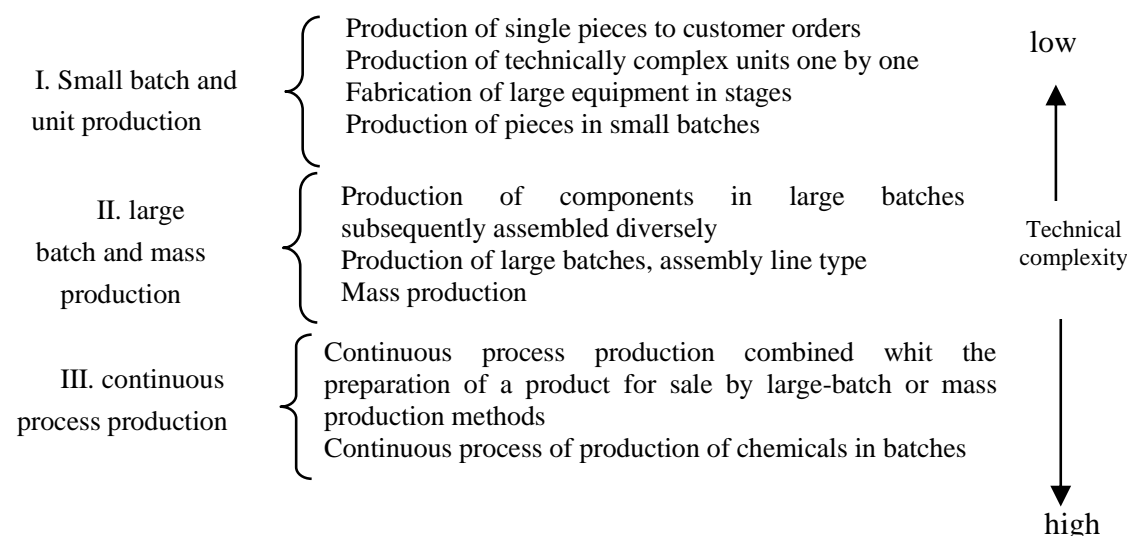

Fig. 1. J. Woodward's typology of technology, [10].

J. Woodward's idea [10] establishes three technological groups ordered according to the technical complexity parameter, i.e. the level of mechanisation of the production process:

- small batch and unit production - less control, less management levels and decentralisation, high employee competences,

- large batch and mass production - highly specialised, routine procedures, more control and centralisation, low employee competences,

- continuous process production - similarly to unit production - based on low level of control and decentralisation, at the same time there are more management levels, high employee competences [10].

Woodward claimed that in case of technologies found at the extremes of the scale, organic structures are most suitable, whereas in case of mass production, mechanistic structures are desirable. This is based on the routine of the work performed with different technologies. Extreme technologies are based on non-routine work (suitable for organic structures); work related to mass production is highly routinized (better adjusted to mechanistic structures). This correlation is shown in Fig. 2. 


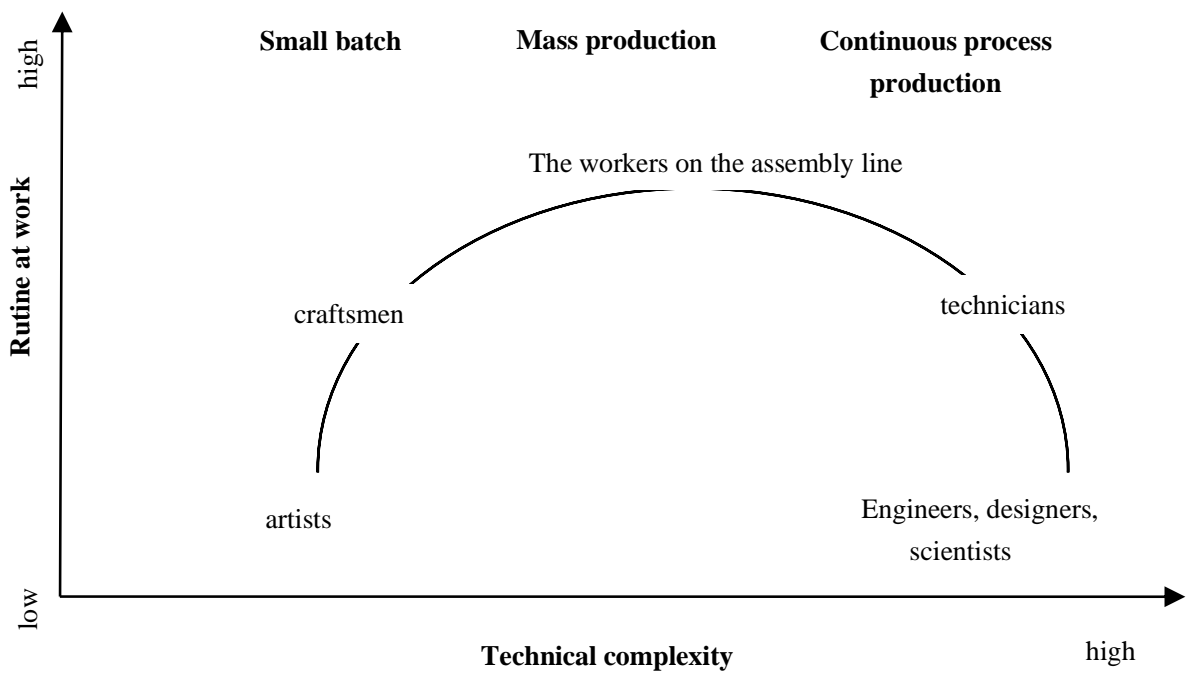

Fig. 2. The relationship between work routines and technical complexity, [10].

Ch. Perrow, cited from [10], also believes that technology is linked to the organisational structure and imposes a specific division of tasks and manner of individual's activities coordination. Technology determines the structure in two ways:

- by distinguishing between the components used - standard or nonstandard materials, frequency of unexpected occurrences, simplicity or complexity of the situation; in other words, it concerns the variability of tasks defined as a number of deviations from standard procedures encountered while using a particular technology [10],

- based on the type of efforts required while making decisions (analysability of the situation) the number of known analytical methods used to deal with deviations encountered [10], which grows with the number of available routine solutions.

Depending on how those two parameters intertwine, C. Perrow, cited from [10], proposes a specific type of organisation, using a specific type of technology (presented on fig. 3). 


\begin{tabular}{l|c|c|}
\multicolumn{1}{c}{} & \multicolumn{1}{c}{$\begin{array}{c}\text { Few exceptions } \\
\text { (Formal structure) }\end{array}$} & \multicolumn{1}{c}{$\begin{array}{c}\text { Massy exceptions } \\
\text { (Flexible structure) }\end{array}$} \\
\cline { 2 - 3 } $\begin{array}{l}\text { Unanalysable decision } \\
\text { (Simple to decentralize) }\end{array}$ & $\begin{array}{c}\text { Craft Technology } \\
\text { (specialty glass) }\end{array}$ & $\begin{array}{c}\text { Nonrutine Technology } \\
\text { (airplanes, rockets) }\end{array}$ \\
\cline { 2 - 3 } $\begin{array}{l}\text { Analysable decision } \\
\text { (Difficult to decentralize) }\end{array}$ & $\begin{array}{c}\text { Rutine Technology } \\
\text { (steel industry, } \\
\text { automotive) }\end{array}$ & $\begin{array}{c}\text { Engineering Technology } \\
\text { (heavy machinery and } \\
\text { equipment) }\end{array}$ \\
\cline { 2 - 3 }
\end{tabular}

Fig. 3. Types of technology according to C. Perrow, [10, 23].

Craft technologies involve low task variability and low analysability. Intuition and experience play a particularly important role in this technology, especially when standard operating methods fail (although usually there are several known solutions which can be relied on) [10]. The structure has organic characteristics (according to H. Steinmann and G. Schreyögg, similarly to the organic structure): moderate level of formalisation and centralisation, relatively wide management range, mostly verbal and lateral communication. Qualifications and experience of staff play an important role, and control and coordination are less significant (training is more important) [22].

Routine technologies involve low task variability and high analysability. In case of deviations from standard procedures, almost always there is a method available to solve the problem [10]. The structure has mechanistic characteristics: high level of formalisation and centralisation, wide management range, vertical communication, low qualifications of the staff, close coordination and control (regulations, budget and reporting) [22].

Engineering technologies involve high variability and task analysability, with many deviations from standard practices, but the staff have known methods of solving the problem at their disposal (usually as a result of advanced or highly advanced training) [10]. The structure shows characteristics closer to mechanistic models: moderate level of formalisation and centralisation, narrow management range, written and oral communication, coordination and control through reporting and conferences, staff selection based on formal education [22].

Nonroutine technologies involve high variability and low task analysability, with many problems and a lack of known methods of solving them, which means that the staff need to search for new operating methods [10]. The structure shows organic characteristics: low level of formalisation and centralisation, narrow management range, extensive experience and high qualifications of staff, lateral communication, coordination and control through group discussions and social norms [22].

During his research on nonroutine technologies, Ch. Perrow [10] focused on technology as the determinant of uncertainty in organisations (the figure below shows the impact of the typology of technology on the level of routine). Technology influences uncertainty through the variability of quality or availability of input factors or variability of the nature of the transformation process. Increased uncertainty creates difficulties in organising the company's activity because it is not certain which actions will be necessary. 
Task Variability

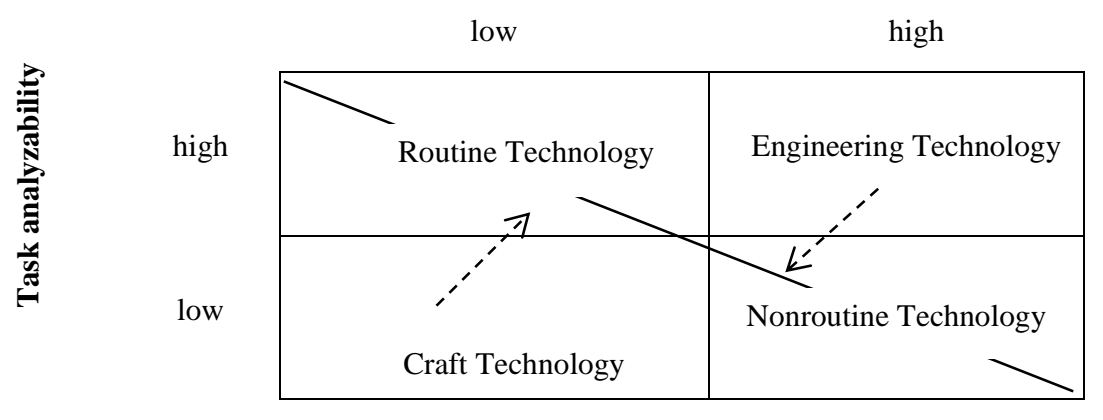

Fig. 4. Effects of two-dimensional typology of technology according to Ch. Perrow on one routine dimension, [10].

Nonroutine technologies require independent staff, professionals and knowledge workers able to use their flexibility to find solutions for constantly changing problems. Their characteristic features include the desire to gain new knowledge, high competences, take innovative approaches (the ability to see opportunities to establish new knowledge, initiating revolutionary changes, showing innovative entrepreneurship, encouraging others to think creatively and working with others in that scope), as well as seeking diversity through cooperation [22]. Morawski indicates that they are able to hold at least four organisational roles in the company, including the role of an innovator who introduces break-through changes independently or in collaboration with other creative members of staff [16]. Knowledge workers, in order to be able to propose nonstandard solutions, require a great deal of freedom in their work, independence and self-reliance. This means that they work well within flexible organisational structures that are much closer to organic solutions with a low level of formalisation and centralisation etc., which facilitates use of the employees' knowledge and aids introduction of nonstandard solutions. It seems, therefore, that the more nonroutine technology is, the more opportunities are created for developing new innovative solutions. The final hypothesis adopted is the following: H: The less routine the technology is in a given enterprise, the higher the company's innovation will be.

\section{The relationship between technology and innovation}

The general aim of the research was to define the determinants of the organisational innovation, with a particular emphasis on the knowledge management processes One questionnaire was sent to each surveyed organisation with the request that a person with a broad view of the whole organisation (i.e. CEO, management team, quality specialist etc.) fill it in. The questionnaire included questions to measure the level of various determinants of innovations and the level of innovation. The survey also dealt 
with questions concerning certain characteristics in order to determine the structure of the surveyed organisations (size, the ownership and position of the organisation). Competent experts (scientists and senior managers) verified the accuracy of the items included in the questionnaire. The experts, independently of one another, made an individual assessment of the questionnaire. Each respondent received a questionnaire and a cover letter (which included the request for help in the research programme, the explanation of the aims and scope of the programme as well as the assurance of anonymity).

To investigate the results of the relation between innovation and technology, the key variables were defined.The innovation variable was measured with 4 indicators:

- the subjective indicator: level of innovation, i.e. the degree to which:

- the organisation's innovation is higher than the innovation of its main competitor,

- many ideas on how to improve the organisational procedures are developed at the organisation,

- many ideas on how to improve the technological process are developed at the organisation,

- many ideas on how to improve the services/products are developed at the organisation,

- ideas created at the organisation are often implemented.

The items were analysed on the basis of the discrimination coefficient and Cronbach's alpha parameter. Cronbach's alpha equalled 0.861 , which shows a very high internal scale and reliability of the measurement of the innovation variable.

- 3 objective indicators (assessed on a 0-1 scale):

- having or not having formal signs of innovation (such as patent applications, granted patents, granted utility models, licences, proprietary rationalisation ideas),

- employing or not employing R\&D staff,

- expenditure or no expenditure on R\&D.

The scale measuring nonroutine technology initially included 4 items. The items were analysed on the basis of the discrimination coefficient and Cronbach's alpha parameter. One item was removed from the scale, as its discrimination coefficient was less than 0.2. The final scale comprised of 3 items, Cronbach's alpha equalled 0.678, which shows a high internal consistency of the scale and reliability of the measurement.

The nonroutine technology variable was measured with the following indicators:

- tasks carried out at the enterprise are very complex,

- tasks carried out at the enterprise are variable,

- work is mostly based on routine activities

In order to examine the relationship between variables and the subjective level of innovation, regression analysis was performed. In case of objective indicators, 
variation analysis was performed to compare the average scores for the nonroutine technology independent variable in groups distinguished on the basis of, respectively: having or not having formal signs of innovation, employing or not employing R\&D staff and expenditure or no expenditure on R\&D. All calculations were performed using SPSS packages for Windows.

The variation analysis concerning the objective indicators and the nonroutine technology variable did not produce statistically significant results. However, it should be considered that the respondents often did not answer the questions concerning R\&D employment figures, R\&D finances, and formal signs of innovation. Whereas the regression analysis showed a significant correlation between the nonroutine technology variable and the innovation variable $[\mathrm{F}(1.103)=17.363$, $\mathrm{p}<0.001]$. The nonroutine technology variable explains $\mathrm{R}^{2}=14.4 \%$ of the innovation variable.

\section{$5 \quad$ Technology and organizational structure - discussion}

While analysing the types of organisational technology favourable to innovation, it is clear that the authors often link technology to the organisational structure, see among others the authors cited earlier in $[10,22]$. It should be pointed out that research on the relationship between structure and innovation points to certain characteristics which also support nonroutine technology- giving the structures a more organic character.

The organisational structure is believed to have the following features: configuration, centralisation, specialisation, standardisation and formalisation (Fig. 5.). Configuration and centralisation determine the place of every employee in the organisation, while specialisation and the other characteristics determine the desired individual and collective activities [11, 19]. 


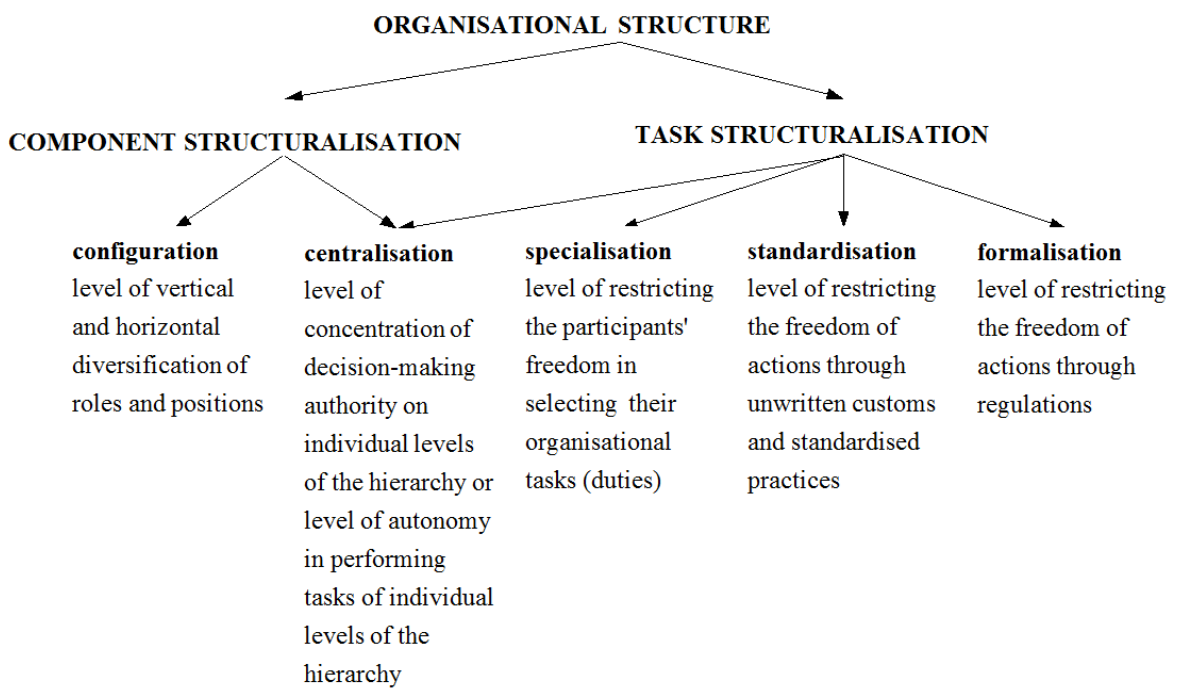

Fig. 5. Structural features according to K. Mreła, [11].

The issue of the degree of work division and specialisation is one of the basic dilemmas while building an organisational structure [2]. From the team perspective, a high level of specialisation is mostly connected to the economies of scale of the operations, as repeatability and inalterability facilitate the use of routine and specialised technology, as well as a better use of specialist qualifications of staff. On the individual level, specialisation involves gaining experience and low requirements in terms of employee qualifications. However, Bielski believes that there is also the other side to this coin. Extensive work division and high specialisation also have negative effects from the team perspective, such as obstructed flow of information between organisational units, as well as decreased work efficiency caused by dissatisfaction with work, which is a very important issue from the perspective of innovation [2]. On the individual level, the following effects have been observed: degradation of people and their qualifications in the work process (with monotony and mental exhaustion), degradation of the role of people in the organisation's operations (separation of conceptual work from executive work), difficulties in seeing the connection between tasks performed and business goals, which also affects the staff's creativity and consequently the organisation's innovation. The main feature of the organisational structure is the basic criterion of specialisation [23]. In the case of departmental specialisation, the ability to implement innovative projects grows with an increased integration of functions involved in the innovation process. At the same time, creating single-function departments may lead to autonomisation of the goals of individual organisational components [16, 20]. Meanwhile, Sikorski describes the impact of positional specialisation on innovation. This type of specialisation limits the likelihood of creating pro-innovation attitudes, which is a result of establishing specific expectations for the staff (separating conceptual work from executive work), low complexity of tasks performed, difficulties in seeing a connection between tasks 
performed at individual posts and a lack of necessary information [19]. It is important to notice that also organizational configuration is an important factor that can support or discourage innovation processes in organization. Flexibility and agility are characterizing structures in innovation-oriented organizations [5]. It can be concluded that factors, which are the most important for innovation should facilitate organictype structure in organization (more flexible and agile then mechanistic structure), which is characterized by low centralization, low formalization, low specialization, and simple hierarchy [24].

\section{Summary}

Modern organisations operate in an increasingly complex environment, where changes occur very dynamically. Maintaining a competitive advantage in such conditions requires more than an individual product, technology or resources - it requires an effort made to ensure that the organisation stands out from the competition thanks to its innovation. Leonard and Straus describe a simple principle of competitiveness: introduce innovations or stay behind [9]. The issue of business innovation is very important in the field of management. Both practitioners and theoreticians considered innovation as one of the factors which determine the success of an organisation. The conditions of innovation are the subject of many scientific publications. However, there is a shortage of empirical studies indicating a clear correlation between the type of technology employed and innovation. The research presented in this article shows that there is a statistically significant relationship between nonroutine technology and innovation. This means that the more variable are the team's tasks and the more varied are the solutions that are applied, the higher level of innovation of the organisation. Technology is also linked to the organizational structure. For example, the nonroutine technology used by companies influences the tasks and skills of employees, and these changes in turn exert an emphasis on modifying the organizational structure towards organic structures. An important dimension of organizational structure is the criterion of specialization. The relationship of specialization to technology, generally refers to the way of division of work. The lower the degree of specialization in the enterprise, the more likely it is to have non-routine technology. As a future studies it would seem interesting to examine the correlation between technology, organizational structure and types of innovation.

\section{References}

1. Baruk, J.: Zarządzanie wiedzą i innowacjami. Wyd. Adam Marszałek, Toruń (2006).

2. Bielski, M.: Organizacja. Istota, struktura, procesy. Wydawnictwo Uniwersytet Łódzki, Łódź (1992).

3. Chesbrough, H., Crowther, A. K:. Beyond hightech: early adopters of open innovation in other industries. R\&D Management, 36(3), 229-236 (2006), DOI: 10.1111/j.14679310.2006.00428.x. 
4. De Cagna, J.: The Six Core Values of Innovation, www. http://changethis.com/ manifesto/41.03.SixCoreValues/pdf/41.03.SixCoreValues.pdf, last accessed 2017/02/02.

5. De Mello, A. M., Marx, R., Saleron, M.: Organizational structure to support innovation: How do companies decide? RAI: revista de administração e inovação, 9(4), 5-20 (2012), DOI: http://dx.doi.org/10.5773/rai.v9i4.623.

6. Dobni, C.B.: Achieving synergy between strategy and innovation: The key to value creation. Int. Journal of Business Science and Applied Management, 5,(1), 48-48 (2010), http://www.business-and-management.org/library/2010/5_1--48-58-Dobni.pdf, last accessed 2017/02/02.

7. Drucker, P.F.: Innowacja i przedsiębiorczość. Praktyka i zasady. PWE, Warszawa, (1992).

8. Gobble, M.M: Innovation and Strategy. Research-Technology Management, 55(30) 63-65 (2012), DOI: $10.5437 / 08956308 \times 5503005$.

9. Harvard Business Essentials: Zarzadzanie kreatywnością i innowacja. MT Biznes, Warszawa (2005).

10. Hatch, M.J.: Teoria organizacji. PWN, Warszawa (2002).

11. Hopej, M.: Struktury organizacyjne: Podstawowe, współczesne i przyszłe rozwiązania strukturalne. Zakł. Nar: im. Ossolińskich, Wrocław (2004).

12. Janasz, W.: Innowacje i ich miejsce w działalności przedsiębiorstw. In: Janasz, W. (eds.) Innowacje $\mathrm{w}$ modelach dzielności przedsiębiorstw. Wyd. Naukowe Uniwersytetu Szczecińskiego, Szczecin (2003).

13. Jaruzelski, B., Dehoff, K.: The Global Innovation 1000. How the Top Innovators Keep Winning. Strategy+Business Magazine, 61, 1-14 (2010), https://www.strategybusiness.com/article/10408?gko=08375, last accessed 2017/02/02.

14. Krzyżanowski, L.: O podstawach kierowania organizacjami inaczej: Paradygmaty, modele, metafory, filozofia, metodologia, dylematy, trendy. PWN, Warszawa (1999).

15. Leavitt, H. J., Whisler, T. L.: Management in 1980s. Harvard Business Review, https://hbr.org/1958/11/management-in-the-1980s, last accessed 2017/02/02.

16. Osęka, M., Wipijewski, J.: Innowacyjność przedsiębiorstw, Ekonomiczne i organizacyjne determinanty. PWN, Warszawa (1985).

17. Padilha, J., Cziulik, C., Beltrao, P.: Vectors of innovation definition for application during conceptual design stage of product development process. J. Technolo. Manag. Innov., 12 (1), 49-60 (2017), DOI: 10.4067/S0718-27242017000100006.

18. Peters, T., Waterman, R., Phillips, J.: Structure is not organization. Business horizons, 23 (3), 14-26 (1980), DOI:10.1016/0007-6813(80)90027-0.

19. Sikorski, C.: Zachowania ludzi w organizacji. PWN, Warszawa (1999).

20. Sine, W., Mitsuhashi, H., Kirsch, D.: Revisiting Burns and Stalker: Formal structure and new venture performance in emerging economic sectors. Academy of Management Journal, 49(1), 121-132 (2006), 10.5465/AMJ.2006.20785590.

21. Srikantaiah, T., Koenig, M.: Knowledge management: for the information professional, medford. Wyd. American Society for Information Science (2001).

22. Steinmann, H., Schreyögg G.: Zarządzanie - podstawy kierowania przedsiębiorstwem. Koncepcje, funkcje, przykłady. Oficyna Wydawnicza Politechniki Wrocławskiej, Wrocław (1998).

23. Strategor copr.: Zarządzanie firmą. PWE Warszawa (2001). 
24. Tworek, K., Walecka-Jankowska, K., Martan, J.: Structure reorganization due to IT information functions support for knowledge management. China-USA Business Review, 14(7), 362-378 (2015), DOI: 10.1007/978-3-319-28564-1_10.

25. Walecka-Jankowska K., Wpływ zarządzania wiedzą na innowacyjność przedsiębiorstw, Rozpr. doktor. PWr, Wydział Informatyki i Zarządzania, Wrocław 2011. 